\title{
Chitra Banerjee Divakaruni's The Palace of Illusions: Challenging a Patriarchal Domain
}

Sabitri Dhakal ${ }^{1}$

\begin{abstract}
Patriarchy has long been the dominant set of norms, rules, beliefs and laws. There are lots of women who are treated unfairly and suffer from male dominance. Draupadi and other women have also been the victims of the patriarchal society. This study aims to analyze the situation of these women in the text. These women have been the major sufferers in terms of their freedom, their rights, their individuality and sexual harassment. In order to bring the issues of women in limelight The Palace of Illusions, authored by Chitra Banerjee Divakaruni was selected. The novel depicts the situation of the women in the ancient period. It reveals the courageous nature of women, and their determination to live a happy life while enjoying their fundamental rights. Moreover, an examination of a sample of book reviews of the novel unveils the important contribution of Chitra Banerjee Divakaruni in the presentation of women as a powerful, courageous and determined being who are able to change history.
\end{abstract}

Key words:

Myth, legend, history, women, feminism, women's rights, marginalisation, awareness, determination, courage, power and change.

Chitra Banerjee Divakaruni's The Palace of Illusions is a retelling of the great Hindu epic Mahabharata. The plot that the novel carries isn't different than the original. However, the narration made through a female character has made it a unique presentation of the story. Instead of choosing any male character as a protagonist in the novel the writer has come up with a female character giving the readers a different approach to look at the already known story of the great Hindu epic.

The Palace of Illusions is a retelling of Mahabharata from Draupadi's perspective. Noting on the narration that is made through a female perspective the project focuses on a feminist reading of the text. Divakaruni's character retelling the modern version of the Mahabharata is noteworthy as she has been able to bring a compelling protagonist in her creation. The retelling of the original is apt in the modern day as it has been able to give justice to the female character the novelist has come forth with. Written in the first person

1 Lecturer at Koteshshor Multiple Campus 
narrative the writer has given spaces for her female character to come forward and narrate their personal experiences in their stories. Abundant spaces given for the females in the novel makes the readers feel that presentation of the already known story written with the feminist approach is more appealing while giving the readers a space to think it through the lenses of feminism. Despite presenting Draupadi as a major cause for the destruction of the Third Age of Man (Dwarapa Yug) and referring to her as a Kritya - one who brings doom to her clan Divakaruni with her wide and magnificent lenses puts forth her central female character with a diverse perspective. Her female character is bold, confident and is determined to achieve the desired goal in her life. She is able to create a history that one remembers even years after. Divakaruni has given a stronger role to the women in her story. The females presented in her story aren't submissive or meek. Neither are they subservient. They are bold and are change makers. They are determined and are achievers. They are presented as an equal to the males in the society. This approach of the author gives one an opportunity to safely argue that The Palace of Illusions is a feminist reading of the Mahabharata.

The storyteller of the novel isn't an ordinary one. She is Panchaali (Draupadi) - the fire born princess. The character Divakaruni has created in her novel is neither submissive nor is subservient but rather she is independent and determined to make choices for her own. The female in novel raises voices for her freedom and rights. This project tries to go beneath the predominantly masculine views about representation of women in literary texts. A feminist literary analysis of the novel has, however, been quite in sparse in comparison to a general patriarchal notion of analysis of female characters in texts in general. This project seeks to plug this critical gap.

The writer has presented Draupadi as a strong character in her novel. She is bold and is able to present herself in the strong role despite being dominated in a patriarchal society. Despite facing the problems and hindrances in her life and being subjugated Draupadi is able to stay bold in her decisions and her acts. Presenting the similar view about the character in the novel Renuka Narayanan in the Hindustan Times writes: "Told in the first person, Divakaruni's tale takes us through the epic in Draupadi's voice. From being born of the sacrificial fire (thus her beautiful name 'Yajnaseni', though the author doesn't use it, preferring 'Panchali'), to her strange, lonely childhood, her tricky marriage to five men with a persecution problem and a control freak mother, her own, lovely home at last, and then the unbelievable traumas that follow that nobody should have to go through (but millions of refugees do)" (12).

Dr S G Puri writes, "Divakaruni in her novel The Palace of Illusions talks of the social conditioning of a woman who descends her positioning in the cultural paradigm. She also talks of the significance of cultural scripts, which provokes a woman to negotiate her 
with space created through undergoing agency. The agency helps the society to have the desired result" (1).

This study is a discerning account of the presentation of the female character and the portrayal of lives of women in the texts. Women of all ages, classes, races, religions and nationalities experience discrimination at different stages of their life. They become victim of violence in the society. Draupadi too is dominated by various male chauvinists in her life. Yet, a determined and an assertive woman she is able to create her self-identity, a woman destined to change the history.

The primary objective of this study is to explore the issues of women. It aims at deconstructing patriarchal binaries in order to establish women as a bold and confident character. Feminism always aims at defining, establishing and defending equal political, economic and social rights for women. It also seeks to establish equal opportunities for women in education and employment. Lois Tyson narrates about the process of analyzing any literary text from a feminist perspective and states, "From a feminist perspective, when we interpret texts or anything else, the way to deal with our subjectivity is not to try to avoid it but to be aware of it as possible, to include it in our interpretation as fully as possible, so that others will be able to take it into account when evaluating our viewpoints" (95).

Feminism is a political movement that emerged in the late 1960s with an aim of defining, establishing and defending equal political, economic and social rights for women both in theory and practice. Feminism speaks to the specificities of geography, culture, and needs of women who were left on the periphery. Feminist theory is inherently linked with women's political movements and their struggle to free themselves from the gender biases of the patriarchal society. It aims to understand the nature of gender inequality by examining women's social roles and lived experiences and focuses on gender politics, power relations and sexuality.

Feminism primarily deals with the unequal relationship between the males and females. Men are in public domain as breadwinners, spiritual leaders and political leaders. However, women are confined within the family as home-makers. Males are supposed to be independent, self-reliant, educated, centered, active and having the knowledge of good and evil; whereas females are supposed to be dependent, weak, emotional, irrational, docile and marginalized. Whatever positive attributes men claimed for themselves, their opposites were affixed to women. In this regard, Simone de Beauvoir in her highly acclaimed book The Second Sex writes: "man represents both the positive and the neutral, as is indicated by the common use of man to designate human beings in general; whereas woman represents only the negative, defined by limiting criteria, without reciprocity" (xv). This presentation of the male as both positive and neutral is resulted from the subordination tendency. 
The position of different social groups in the social and political space is not always equal in practice. This is particularly so in the case of women. The nature of society has a decisive impact on the extent and effectiveness of women's presence, participation, and protection of their individual rights. The issue of inequality of men and women has always been widely discussed in human society. Generally, women have been seen as inferior to men in terms of their qualities, capacities and their roles in society. Patriarchy fosters gender-based inequalities that decides male as superior and women as inferior, man as powerful and female as powerless. Patriarchy considerably gives the right only to the males so that females are left as the desirable beings of males. In a patriarchal society, male treats female as a thing but not as a human being. Women have to live in formulated expression and discrimination on the basis of sex, race, age, class, religion etc. in such societies. Men are always overpowered with the sense of "I am man; she is woman. I am strong; she is weak. I am tough; she is tender. I am self-sufficient; she is needful” (Ruth 55).

Simone de Beauvoir has also defined the 'woman' and her identity in the social discourse. Opening up on how women have been taken and are considered she writes in The Second Sex, "Woman? Very simple, say those who like simple answers: she is a womb, an ovary; she is a female: this word is sufficient to define her. From a man's mouth, the epithet 'female' sounds like an insult; but he not ashamed of his animality, is proud to hear: 'He is male!' The term 'female' is pejorative not because it roots woman in nature, but because it confines her in her sex" (21).

Women have often been defined as relative to men. Their identity is attached with the men in their life. Neither she does have her own identity nor is she autonomous. Beauvoir further adds, "male and man defines woman not in herself but as relative to him; she is not regarded as an autonomous being" (44). However, leaving behind the patriarchal norms and set rules for the women Divakaruni has brought forth the female character who is strong and bold enough to challenge the male dominated society. The novelist has seen Draupadi as one of the powerful and independent character. Draupadi is presented as the one who is able to fight for her liberation. Able to affirm her individuality, self-esteem and an urge to make a self-identity, we find her challenging the patriarchal society. The character Divakaruni has portrayed as a narrator is powerful, strong and an independent woman who refuses to believe that a woman's identity should be bound by men in her life. She doesn't like to take the name her father has given her. That's why she rejects her identity Draupadi (literally meaning the daughter of Drupada) and renames herself Panchaali (meaning derived from the Kingdom of Panchaal). The hatred of Draupadi is clearly seen in the novel:

He said to your brother, I name you Dhristadyumna. He said to you, I name you Draupadi. And when we had the best feast his kingdom has ever seen.... Dhri's name fell within the bounds of acceptability - though if I were his 
parent I might have picked a more cheerful appellation, like Celestial Victor, or Light of the Universe. But daughter of Drupad? Granted, he hadn't been expecting me, but couldn't my father have come up with something like less egoistic? Something more suited to a girl who was supposed to change the history? I answered to Draupadi for the moment because I had no choice. But in the long run, it would not do. I needed a more heroic name. (5)

Fully aware about her situation and the importance of education in her life she expresses her need to become educated. "These were the lessons I most envied him, the lessons that conferred power. They were the ones I needed to know if I were to change history" (27). She is a revolutionary character. She fights to get her right to education. Even when she is getting education she is discouraged by the tutor himself. There are prominent evidences in the novel to prove it.

"O great prince," he said now, "kindly ask your princess to refrain from prompting you. She is not helping you to learn. Will she be sitting behind you in your chariot in battle when you need to remember these important precepts? Perhaps it is best if she no longer joins during your studies."

He was always trying to discourage me from attending Dhri's lessons and he wasn't the only one. A first, no matter how much I begged, King Drupad had balked at the thought of me studying with my brother. A girl being taught what a boy was supposed to learn? Such a thing had never been heard of in the royal family of Panchaal! Only when Krishna insisted that the prophecy at my birth required me to get an education beyond what women were usually given, and that it was the king's duty to provide this to me, did he agree with reluctance. (23)

Bold and determined she didn't let the chance to educate herself from her life. Rather she started to protest the discouragement silently and with smiles when she and her brother were taught about 'women'.

Additionally, I resented the tutor's declaration that women were the root of all the world's troubles. Perhaps that was why, when he gathered up his palm leaf manuscripts and rose to leave, I pushed the curtain aside and gave him a brilliant smile as I bowed. The effect was better than I had hoped. He jumped as though stung; manuscript fell, helter-skelter, from his hands. I had to pull the end of my sari over my face to hide my laughter, although I knew there would be trouble later. But inside a current surged through me at the discovery of a power I didn't know I had. (24-25) 
Women are regarded as the one who need to take care of men. They should be able to please men. Women should know how to accomplish household tasks and the art and crafts necessary to please a man. Her beauty and her feminine qualities are given much priority than her intellectuality.

Also, in R.K.Narayan's The Indian Epics Retold, Yudhishtira describes Panchali as "the goddess Lakshmi herself in stature, grace and complexion; eyes like lotus petals; a woman who is an ideal wife to guide, serve and sustain a man at all times" (260). Contradicting the above hierarchical notions, Banerjee has come up with a powerful voice to justify the important role of women in her epic. Her female character doesn't like being the woman the society wants her to be.

I was given lessons in singing, dancing, and playing music. (The lessons were painful, both for my teachers and me, for I was not musically inclined, nor deft on my feet.) I was taught to draw, paint, sew, and decorate the ground with age-old auspicious designs, each meant for a special festival. (Mt paintings were blotchy, and my designs full of improvisations that my teachers frowned at.) I was better at composing and solving riddles, responding to witty remarks, and writing poetry, but my heart was not in such frivolities. With each lesson I felt the world of women tightening its noose around me (29).

The character Divakaruni has presented is an individual woman who is rebellious in nature. She can't live a happy life under the control from the men in her life. Despite her brother forcing her to concentrate in feminine interests she is determined to learn what a king was supposed to know. Therefore she secretly learns war skills and political lessons which men were only supposed to learn then. She is able to make her decisions on with whom to get married.

People with dark skin colour had to pass through racial discrimination and the condition of women were more difficult. Draupadi too had to undergo with various difficulties but she befriended Krishna - a dark skinned man. "Perhaps the reason Krishna and I got along so well was that we were both severely dark-skinned. In a society that looked down its patrician nose on anything except milk-and-almond hues, this was considered most unfortunate, especially for a girl. I paid for it by spending hour upon excrutiaitng hour being slathered in skin-whitening ungguents and scrubbed with numerous exfoliants by my industrious nurse" (7). People tried to teach Draupadi the feminine nature dancing and walking slowly and other attributes of females. Beauvoir too writes, "One is not born, but rather becomes, woman. No biological, psychical, or economic destiny defines the figure that the human female takes on in society; it is civilization as a whole that elaborates this intermediary product between the male and eunuch that is called feminine" (293). Draupadi 
was aware of the situation and didn't comply with the general notion of the women how they were supposed to be. "Women are subject to economic constraints and discrimination, which are usually imposed on them to a greater degree than men, both within and outside of the family. Another cultural norm that maintains women's submissiveness and inferiority is reflected in the attitude that children cannot be raised in an appropriate and healthy way by one parent, and all the more so if the mother raises them alone, without a father" (3) writes Muhammad M. Haj-Yahia in his article On the Characteristics of Patriarchal Societies, Gender Inequality, and Wife Abuse: The Case of Palestinian Society. But the character Kunti had raised her all five sons without a father more appropriate and healthy ones that a society envies to make such children. Her character Kunti is able to raise five children in the absence of their father. She is able even to keep all her child in her control and even is able to help them get their position. The evidence is seen in the text when Arjun brings home Draupadi for the first time. She tells him to share it with his brothers whatever he has brought. Kunti devoted her life to help the Pandava brothers to become royal kings. In this regard, Divakaruni has not only presented her central character in a powerful role but she has also portrayed other female characters in the text as the powerful ones. Kunti was even bold enough to deliver a child before getting married in the then society. It shows how the women were willing to take a risk than to stay on the comfort zone in the then time. Shikhandi with her reincarnation takes revenge with Bheesma for the assault he has done to her. Not only them but Draupadi even stands bold and speaks when she was supposed to remain silent during a ceremony where she was to choose her better half. Not only that but even after getting married with Arjuna she was divided with all other four brothers. She manages all of them and plays a vital role in keeping an intact relationship between the brothers in the family. She is powerful and an independent character who fights with the males for her liberation. To affirm her individuality and her self esteem she fights, and does her best that she needs to come forth with. Despite Yudhisthira losing her in the game of dice to his opponent Duryodhan and being sexually harassed in the King's court she doesn't lose her hope. Rather she takes a vow to never tie her hair until and unless she dips her hair in the blood of those opponents. It was a challenge for the male dominated society where a female was supposed to be a weak character. She is able to prove herself that indeed she is courageous and is able to take revenge with the perpetrators. She was not the one who would let the things go off her hand. Rather she became the cause for the Pandava brothers to settle their family disputes. Women are supposed to be emotional and sympathetic but here Draupadi is presented as a woman full of revenges. Women who weren't expected to see war has become the cause of war. Not only the cause but here Draupadi is also given the 'special vision' of seeing the important parts of the Great War between the Pandavas and the Kauravas. Hidimba, Bheem's other wife raises the child on her own and even sends him to the war. 
Not only Draupadi but there are some other characters who are presented as a strong character in the novel. If we are to look at Gandhari then we can see her as a bold character who has sacrificed her vision for the sake of her visually impaired husband. She has made a great sacrifice in her life that none of the males would do in their life by blindfolding herself. Uttara who has even lost her husband Abhimanyu in the war is hopeful of her child that she is carrying in her. Despite being in the trauma of losing her husband she is hopeful about the future. All these shows that women do not stick on the same old thing rather they prefer to move ahead with the flow of the time.

In a conversation between Dhai Ma and Draupadi we come to know that how a female is taken into account when she has sexual relationship with more than one man."You know what our shastras call women who've been with more than one man, don't you? Though no one seems to have a problem when men sleep with a different wife each day of the week!" (42). However, Draupadi being married with five men in her life is able to remove the tag of "slut" the society calls for women who sleep with multiple men. The virginity of the women was supposed to be protected. Neither anyone should touch them nor should the women think about any men. Doing such things would make them corrupted. In the conversation between Shikhandi and Panchaali when Shikhandi narrates the conversation between Salva and Amba we come to know that the women are of nowhere if someone touches her. However the women in Divakaruni's novel are fully aware of such situations and their sexual rights where Amba protesting says that: "If someone grasps my hand against my will, how does that make me his? I said, I'm the one who decides to whom I belong" (48). The characters the novelist has created are bold enough to know their status and are fully aware about it. The women described in the text are more aware about the men around them. Draupadi even was aware about her father who was a representative of the male patriarchal society. However she was decisive and was bold enough. "In his own harsh and obsessive way, he was generous, may be even indulgent. But I couldn't forgive him that initial rejection. Perhaps that was why, as I grew from a girl into a young woman, I didn't trust him completely" (6). This shows how the women are able to make decisions on their own and use their fundamental rights accordingly.

Human civilization has historically been patriarchal or male dominated. The dominaiton and subjugation of women is clearly seen in the text. But despite those discrimination and subjugation women have come up with their powerful nature. How they have been able to give decisions on the actual time, how they have been able to raise the family in the absence of their better halves these women are actually bold enough to become an exemplary in the society. They are able to create an identity of their own while rejecting the norms and values that have always marginalized the women. While challenging the patriarchal norms and values of the society these women have proved themselves to be someone not less than their male counter parts. 


\section{Works Cited}

Beauvoir, Simone de. The Second Sex. 1949. Trans. H.M. Parshley. Harmondsworth: Penguin, 1972.

Divakaruni, Chitra Banerjee. The Palace ofIllusions. New York: The Doubleday Broadway Publishing Group, 2008.

Dr Puri, S G. "Replication of the Cultural Scripts in Chitra Banerjee Divakaruni's The Palace of Illusions." Contemporary Literary Review India 2:3 (Aug, 2015): 1-5

Haj-Yahia Muhammad M. "On the Characteristics of Patriarchal Societies, Gender Inequality, and Wife Abuse: The Case of Palestinian Society.” Adalah's Newsletter 20 (Nov, 2005$): 1-3$.

Narayan, R K. The Indian Epics Retold. Viking: Penguin Books India, 1995.

Narayanan, Renuka. "Review: The Palace of Illusions." Hindustan Times 13 April, 2008:12

Ruth, Sheila. Issues in Feminism. Boston: Houghton Miffin Company, 1990.

Tyson, Lois. Critical Theory Today. New York: Routledge, 2006. 
